\title{
Reseña de Fernando Villalón, Islas del Guadalquivir, edición de Jacques Issorel, Sevilla, Renacimiento, Antologías $\mathrm{n}^{\circ} 105,2018$
}

\section{Claudie Terrasson}

\section{(2) OpenEdition}

Journals

Edición electrónica

URL: http://journals.openedition.org/agedor/3885

DOI: 10.4000/agedor.3885

ISSN: 2104-3353

Editor

Laboratoire LISAA

Referencia electrónica

Claudie Terrasson, « Reseña de Fernando Villalón, Islas del Guadalquivir, edición de Jacques Issorel, Sevilla, Renacimiento, Antologías n¹05, 2018 », L'Âge d'or [En línea], 11 | 2018, Publicado el 19

diciembre 2018, consultado el 24 septiembre 2020. URL : http://journals.openedition.org/agedor/3885 ; DOI : https://doi.org/10.4000/agedor.3885

Este documento fue generado automáticamente el 24 septiembre 2020.

L'Âge d'or. Images dans le monde ibérique et ibéricoaméricain 


\title{
Reseña de Fernando Villalón, Islas del Guadalquivir, edición de Jacques Issorel, Sevilla, Renacimiento, Antologías n¹05, 2018
}

\author{
Claudie Terrasson
}

\section{REFERENCIA}

Fernando Villalón, Islas del Guadalquivir, edición de Jacques Issorel, Sevilla, Renacimiento, Antologías n 105, 2018, 296 páginas

1 La editorial Renacimiento que cuenta con una colección cuidada y elegante de antologías poéticas acaba de publicar una edición de la obra del poeta del 27 Fernando Villalón, al cuidado de Jacques Issorel. Gran hispanista francés, catedrático en la universidad de Perpiñán, Jacques Issorel es autor de muchos estudios y libros que versan sobre la poesía española contemporánea y aúrea: entre los más recientes, citemos un libro dedicado a los Últimos días en Collioure, 1939 y otros estudios breves sobre Antonio Machado (Sevilla, Renacimiento, 2016) y un estudio "Sobre amor y erotismo en las Soledades de Luis de Góngora" (en Quaderni ibero-americani, 108, Bologna, Grausedizioni, Gennaio-dicembre 2018). La publicación de Renacimiento a los veinte años de la edición en Cátedra de las obras completas por el mismo J. Issorel marca así un ciclo que supone la vitalidad de los trabajos sobre Villalón. De ello da fe otro libro de Jacques Issorel particularmente útil para los estudiosos por proponer una bibliografía casi exhaustiva: Fernando Villalón, la pica y la pluma. Perfil biográfico, estudio, antología y bibliografía (Sevilla, Espuela de plata, 2011).

Islas del Guadalquivir empieza por un prólogo (7-25) suficientemente nutrido como para recordar lo esencial de la trayectoria vital y poética del conde de Miraflores de los Ángeles, igualmente ganadero y poeta, Fernando Villalón. Como lo expone J. Issorel lo 
relevante es la concentración en tan poquísimos años de la casi totalidad de la obra del poeta. En efecto Villalón publicó sus tres libros mayores entre 1926 y 1929: Andalucía la baja (1926), La Toriada (1928), Romances del 800 (1929). Presa de dificultades de todo tipo y aquejado gravemente por problemas de salud, Villalón quiso luchar contra el tiempo en una carrera desesperada (murió en una clínica de Madrid el 8 de mayo de 1930) y triunfante a la vez porque logró que se publicasen sus poemarios. No por nada, Issorel evoca la urgencia y "febrilidad" del hombre y del poeta a lo largo de aquellos pocos años tan intensos. Ahora recalca también cómo tal prisa le resultó fecunda al llevarlo a fundar (junta a Adriano del Valle y Rogelio Buendía) una de las revistas más prestigiosas de la vanguardia hispánica, Papel de Aleluya. Hojillas del calendario de la nueva estética (1927-1928).

Después de esta semblanza que hace de introducción al acontexto vital del poeta, sintetiza Issorel las claves de la poesía villaloniana: su independencia ante las normas (sociales como académicas) y su amor a la tierra andaluza. Pone de realce la apertura de un hombre que se muestra consciente de los cambios venideros (fin de la monarquía y llegada de la segunda república), que incluso los anticipa por afirmar su sensibilidad solidaria con los humildes, por satirizar los prejuicios de su clase, por dejar constancia de su preocupación por preservar el ecosistema frágil de las marismas del Guadalquivir. Expone J. Issorel cómo supo Villalón interesarse asimismo por la teosofía en boga entre las vanguardias dejando testimonio de ello con un poema extenso Lubricán "que posee todas las características de un manuscrito terminado" (23).

4 Cabe añir que ofrece la antología una selección bibliográfica (26-31) y la necesaria advertencia sobre la edición (32-33). No falta el aparato crítico que aparece bajo forma de notas finales (287-296): dichas notas aclaran con una brevedad eficaz ciertos elementos de los poemas como son los andalucismos, formas dialectales o nombres propios.

5 La selección operada por Jacques Issorel es interesante porque logra preservar una visión significativa de la obra: hace una síntesis de Andalucía la baja (no conserva los primeros textos, "Las tres marías atlánticas", "Momentos de la ciudad", "Momentos del campo") sin sacrificar lo esencial del espíritu del poemario; igualmente ofrece una muestra representativa del poema épico La Toriada; los Romances del 800 aparecen casi completos (solo se acorta la parte final) y le permiten al lector sentir las opciones liberales del poeta. A continuación viene un amplio abanico de textos diversos- los publicados en revistas, los póstumos y los que quedaron inéditos hasta 1985, entre los cuales el poema Lubricán en su totalidad. Jacques Issorel los reúne por temas: los taurinos, los variados.

6 Como lo sugiere el propio Jacques Issorel, el lector interesado por la figura tan intensa y fuera de lo común de Fernando Villalón lo mismo que por su poesía, que logra aunar tradición y modernidad, fidelidad y ruptura, completará la lectura de esta nueva antología con la de la reedición reciente de Recuerdos de Fernando Villalón (Renacimiento, 2017), libro de Manuel Halcón primo hermano del poeta.

7 Al titular la antología Islas del Guadalquivir (título de un poema de Andalucía la baja [41-42] manifiesta el antólogo la fuerte unidad y coherencia de la obra entorno a una Andalucía tradicional y abierta a la modernidad a un tiempo. Es notable comprobar que el poema epónimo "Islas del Guadalquivir" (42) al evocar la huida del toro por el río ante el avance ruidoso de un buque anticipa $L a$ Toriada en que asistimos igualmente a la fuga de esos mismos toros ante la invasión y destrucción de las marismas por el tractor 
de los hombres. Manifiesta obviamente aquí el poeta una sensibilidad por la naturaleza y su preservación que no descarta la fascinación por las máquinas como se comprueba en varios poemas dedicados al coche, a la velocidad celebrada por Marinetti como nuevo paradigma de la belleza. En cuanto a las islas del Guadalquivir, es lícito leer en ellas más allá de un referente, una metáfora metatextual: son los poemas villalonanos como otras tantas "ínsulas extrañas" semejantes a las que evoca la esposa amorosa del Cántico espiritual.

8 La antología le permite al lector descubrir que las múltiples islas poéticas de Fernando Villalón dibujan un universo arraigado y personalísimo a la vez. Dentro de la llamada (con razón o sin ella) generación del 27, el poeta figura doblemente una isla: por su singularidad y por haber quedado apartado por la historiografía. En ese sentido el título Islas del Guadalquivir es todo un acierto.

\section{AUTORES}

\section{CLAUDIE TERRASSON}

Laboratoire LISAA (EA 4120), Université Gustave Eiffel 